\title{
Exploring the Views of Mosque Committee Members on Mosque Religious Education Programs in Gombak
}

Shukran Abdul Rahman, Lihanna Borhan, Majdan Alias, Mohd Noh Abdul Jalil, Khamsiah Ismail, Che Razi Jusoh, Aliza Elias, Mohd Helmi Mohd Sobri, Muhammad Ayman Al-Akiti, Sofiah Shamsudin, \& Che Mahzan Ahmad International Islamic University Malaysia, Kuala Lumpur, Malaysia

Email: shukran@iium.edu.my

Kamaruzzaman Abdul Manan

Universiti Pendidikan Sultan Idris, Perak, Malaysia

Article History:

\begin{tabular}{|l|l|}
\hline Received: April 26, 2021 & Accepted: November 11, 2021 \\
\hline Revised: July 30, 2021 & \\
\hline
\end{tabular}

\section{Abstract}

There is a multitude of social problems characterized by the growth of crime rate of violence, religious disintegration, hatred, religious disunity, and tension. Such problems have raised serious attention from various parties as they lead to social disintegration and eventually harm social security. The phenomena could be attributed to, inter alia, the lack of religious understanding; a critical factor in constructing the moral behavior of human beings. A study has been conducted to obtain feedback from mosque committee members in Malaysia on the nature of the mosque religious education curriculum. Focus Group Discussions had been conducted by engaging relevant stakeholders of mosques to identify the views of mosque committee members on the mosque religious education curriculum in the district of Gombak, a district in the state of Selangor, Malaysia. The findings have been analyzed using thematic analysis. The findings show that mosque committee members highlighted several issues which concern mosque religious education structure, education resources, participants' content of curriculum, teaching 
and learning approaches, and their expected outcomes. The findings increase the understanding of the roles of mosque as strategic center for community members to acquire knowledge, important for the community sustainable development. The information can be used as basis for the development of the Mosque Religious Education Curriculum.

Keywords: Committee Members, Mosque Religious Education Curriculum, Education Program, and Social Issues.

\section{Abstrak}

Banyaknya masalah sosial yang ditandai dengan meningkatnya angka kriminalitas kekerasan, disintegrasi agama, kebencian, perpecahan dan ketegangan agama. Permasalahan tersebut telah mendapat perhatian serius dari berbagai pihak karena dapat menimbulkan disintegrasi sosial dan pada akhirnya akan merugikan jaminan sosial secara keseluruhan. Fenomena tersebut dapat dikaitkan dengan, antara lain, kurangnya pemahaman agama; faktor penting dalam membangun perilaku moral manusia. Sebuah studi telah dilakukan untuk mendapatkan umpan balik dari anggota komite masjid di Malaysia tentang sifat kurikulum pendidikan agama masjid. Diskusi Kelompok Terfokus telah dilakukan dengan melibatkan pemangku kepentingan masjid yang relevan untuk mengidentifikasi pandangan anggota komite masjid tentang kurikulum pendidikan agama masjid di distrik Gombak, sebuah distrik di negara bagian Selangor, Malaysia. Hasil temuan dianalisis menggunakan analisis tematik. Temuan menunjukkan bahwa anggota komite masjid menyoroti beberapa masalah yang menyangkut struktur pendidikan agama masjid, sumber daya pendidikan, isi kurikulum peserta, pendekatan belajar-mengajar dan hasil yang diharapkan. Temuan ini meningkatkan pemahaman tentang peran masjid sebagai pusat strategis untuk memperoleh pengetahuan untuk pembangunan berkelanjutan. Informasi tersebut dapat digunakan sebagai dasar pengembangan Kurikulum Pendidikan Agama Masjid.

Kata kunci: Anggota Panitia, Kurikulum Pendidikan Agama Masjid, Program Pendidikan, dan Masalah Sosial. 
Exploring the Views of Mosque Committee Members...

\section{INTRODUCTION}

In the current world, individuals are confronted by a multitude of social problems, from the growth of crime rate and violence to religious disintegration and hatred. A study conducted by Ipsos in 2018 shows that crime and violence are the third most mentioned worry in Malaysia and moral decline ranks at the fourth. Meanwhile, Selangor Islamic Religious Department revealed that over 350 followers of deviant teachings were arrested from the year 2015 to 2017 in Selangor. In the District of Gombak, there exists an active community of deviant teaching followers, although it has been ruled as a deviant group in 1989. This shows an upsurge of religious issues which has raised serious concern and attention from various parties for they lead to various psychosocial issues such as social disintegration which will eventually harm the national security.

Many have attributed the above scenario to the lack of religious understanding. The Pew Research Center's Survey in 2014 revealed that 89 percent of Malaysians agree that faith and morality are interrelated. ${ }^{1}$ As religions play a significant role in constructing the moral behavior of human beings, unclarity and lack of understanding of them would lead to moral decline and cause many social problems. ${ }^{2}$ Good religious understanding helps Muslims to see beyond cultural, racial, and political lines, essential in the efforts to mitigate social problems.

\footnotetext{
${ }^{1}$ The Pew Research Center, "Worldwide, Many See Belief in God as Essential to Morality" (Washington, DC: The Pew Research Center, March 13, 2014), https://www.pewresearch.org/global/2014/03/13/worldwide-many-see-belief-in-god-asessential-to-morality/.

${ }^{2}$ Hazizan Md. Noon et al., "Religiosity and Social Problems in Malaysia," Intellectual Discourse 11, no. 1 (June 30, 2003): 77-87; Abe W. Ata, "Perception of Muslims and Islam in Australian Schools: A National Survey," in Religion and Social Problems, ed. Titus Hjelm, 1st Edition (London, UK: Routledge, 2010); Yasemin El-Menouar and Melanie Becker, "Islam and Integration in German Media Discourse," in Religion and Social Problems, ed. Titus Hjelm, 1st Edition (London, UK: Routledge, 2010).
} 
As far as Muslims are concerned, much has been addressed on their development of religious understanding, especially that pertains to the roles of the mosque in shaping Muslims' characteristics. The roles of the mosque as a uniting and harmonizing agent particularly for Muslim individuals in a community, and between Muslim and Non-Muslim members of the society have been historically proven. ${ }^{3}$ In the present Malaysian context, the significant roles of the mosque could be revived with the development of a much more structured religious study curriculum for mosque education programs, hence serving to meet the spiritual and intellectual needs of various groups in the society.

Prominent Islamic scholars believed that Islamic teaching is sine qua non in the process to nurture sound moral characteristics and shape desirable behaviors among people. Religious teaching would provide fundamentals that drive individuals to continuously pursue excellence in all aspects of life. Religious knowledge and principles should be able to substantiate individuals' way of living and motivate them to have excellence in this world and in the hereafter. Religious education is essential as it leads people to learn, relearn and undertake religious practices which would promote the wellbeing of individuals, families, and the community, evident in findings of various mental health research. ${ }^{4}$ Various social science studies found that 81 percent of the 99 studies reviewed found "some positive association between religious involvement and greater happiness, life satisfaction, morale, positive affect or some other

\footnotetext{
${ }^{3}$ Cemil Oruç, "The Impacts of Religious Education on Individual and Social Life," Dinbilimleri Akademik Araştırma Dergisi 10, no. 3 (June 1, 2010): 195-211.

${ }^{4}$ Patrick Fagan, "Why Religion Matters Even More: The Impact of Religious Practice on Social Stability," Backgrounder (Washington, DC: The Heritage Foundation, December 18, 2006), 200, https://www.heritage.org/civil-society/report/why-religion-matters-even-more-theimpact-religious-practice-social-stability.
} 
measure of well-being". This is because religious education gives greater hope and a greater sense of purpose in life. ${ }^{5}$

These findings on the benefit of religious education emphasize the importance of providing Muslims with effective religious education either via the formal or informal system. Regarding the latter, religious education provided at mosques is viewed as a good mechanism in promoting and providing religious education to the population. It is, hence, essential to avail a proper structure of mosque religious education curriculum which would provide Muslims with comprehensive religious knowledge which would empower them to adopt a good way of living and in turn attain a high quality of life in the physical, emotional, intellectual, spiritual, and social aspects.

In attaining this aspiration, there is a need to have a good mosque education curriculum. The curriculum must be based on the needs of a mosque's community, meriting the essentiality to consider the uniqueness and particularity of each locality in terms of the social, economic, and cultural expectations. It is with this understanding that this research has been conducted to identify the views of mosque committee members pertaining to existing mosque religious education programs, its content, implementation, or effectiveness, as the committee members have traditionally been instrumental in deciding the religious education programs for the mosque community. The push for a formal or at least a structured

\footnotetext{
${ }^{5}$ Mahyuddin Barni and Diny Mahdany, "Al Ghazāli’s Thoughts on Islamic Education Curriculum,” Dinamika Ilmu: Jurnal Pendidikan, December 31, 2017, 251-60, https://doi.org/10.21093/di.v17i2.921; Byron R. Johnson, Ralph Brett Tompkins, and Derek Webb, "Objective Hope: Assessing the Effectiveness of Faith-Based Organizations: A Review of the Literature" (New York, NY: Center for Research on Religion and Urban Civil Society, Manhattan Institute, January 2, 2002), https://media4.manhattaninstitute.org/pdf/crrucs_objective_hope.pdf.
} 
education program is not new, ${ }^{6}$ but it has yet to materialize. The findings of the study will serve as a set of bases to develop a structured mosque religious education curriculum that contains comprehensive content and an effective mode of teaching and learning methods. The information is also useful to inform the development of other interventions that could be developed to optimize the functions of mosques in community development.

\section{LITERATURE REVIEW}

The functions of the mosque as a central spine for community development have been historically proven. The mosque institution played significant functions in changing the society during and after the Prophet's time, being the center to educate community members, develop their capacity to become good individuals in the society and change their socio-economic condition to be of a better state. ${ }^{7}$ Mosque institution has been playing the role of a uniting and harmonizing agent for many people, including between Muslims and people of other faiths.

Mosques provide religious education, helping the community members to meet their religious and spiritual needs, being aware of the essentiality of religious teaching and values in nurturing positive behaviors. ${ }^{8}$ They also serve as community places for marriage

\footnotetext{
${ }^{6}$ Nizaita Omar et al., "Framework of Empowering Mosque Institution in Malaysia," International Journal of Academic Research in Business and Social Sciences 9, no. 9 (September 25, 2019): 753-62.

${ }^{7}$ Spahic Omer, "Some Lessons from Prophet Muhammad (SAW) in Architecture: The Prophet's Mosque in Madīnah,” Intellectual Discourse 18, no. 1 (June 29, 2010): 115-40; Spahic Omer, "The Form and Function of the Prophet's Mosque during the Time of the Prophet," Muslim Heritage (blog), August 4, 2020, https://muslimheritage.com/function-ofthe-prophet-mosque/; Mustafa Yïgitoğlu and Mustafa Göregen, "Economic and Commercial Relations of the Prophet Muhammad with the Jews," Afro Eurasian Studies 7, no. 2 (December 31, 2018): 236-53, https://doi.org/10.33722/afes.475785.

${ }^{8}$ Dhini Dewiyanti and Hanson E. Kusuma, "Spaces for Muslims Spiritual Meanings," Procedia - Social and Behavioral Sciences, AcE-Bs 2012 Bangkok, Sukosol Hotel, Bangkok,
} 
solemnization ceremonies, religious education for children, and other communal events. In addition to the congregational prayers, mosques provide a platform for the mass to improve on their understandings of the teachings of Islam through its continuous series of informal classes.

The educational function continues to be seen even during the pandemic. Many mosques provide a religious lesson for mosquegoers and the public in a physical setting or over radio or other platforms of live streaming. In Singapore, mosques officials develop various programs on videos to be broadcast or shared with the community. In Australia, mosques provide live streaming supplication and lectures, while in Malaysia, mosques conduct live streaming tadarrus (group recitation of Quran), as well as religious talks and supplication on YouTube. Like teachers in schools or academics in universities, officials and teachers at mosques have also adopted new modes of conducting religious classes or guidance sessions, many of them have adapted the digital skills to take up new approaches in educating the community.

During the restricted mode of the pandemic, religious classes instructors (ustaz and ustazah) adopt new mode of conducting religious classes or guidance session and have quickly acquired digital skills to take up the new approach of educating the community. Many mosques become forefront centers in dealing with the community members. ${ }^{9}$ They come forward to provide

\footnotetext{
Thailand, 16-18 July, 2012, 50 (January 1, 2012): 969-78, https://doi.org/10.1016/j.sbspro.2012.08.098; Intan Salwani Mohamed et al., "Mosque Fund Management: Issues on Accountability and Internal Controls," Procedia - Social and Behavioral Sciences 145 (August 25, 2014): 189-94, https://doi.org/10.1016/j.sbspro.2014.06.026.

${ }^{9}$ Maryam Alfaraidy and Raffaello Furlan, "Sense of Community in Al-Wakrah City: Strategies for the Development of Sustainable Communities in Qatar," Saudi Journal of Engineering and Technology 2, no. 11 (2017): 390-402, https://doi.org/10.21276/sjeat.2017.2.11.1; Alean Al-Krenawi, “The Role of the Mosque
} 
psychological, spiritual, and social inputs to help ease the society in dealing with the impact of movement restriction; or minimize psychological issues. They provide psychosocial education amongst mosque-goers, conduct workshops to develop capacity related to spiritual, socio-economic, cultural, medical, and psychological aspects of the community members. ${ }^{10}$ Many other approaches have been used by mosque administrative from the west to the east, indicative of how mosques can in fact become an integral part within societal development. ${ }^{11}$

and Its Relevance to Social Work," International Social Work 59, no. 3 (May 1, 2016): 359-67, https://doi.org/10.1177/0020872815626997; Harbi Hayette, "The Role of the Mosques in Promoting Cohesion in the American Community," Revue Académique Des Études Humaines et Sociales 19 (2018): 75-80; Choirul Mahfud, "Chinese Muslim Community Development in Contemporary Indonesia: Experiences of PITI in East Java," Studia Islamika 25, no. 3 (December 4, 2018): 471-502, https://doi.org/10.15408/sdi.v25i3.6755; Earle H. Waugh, Al Rashid Mosque: Building Canadian Muslim Communities (Edmonton, Alberta, Canada: University of Alberta Press, 2018).

${ }^{10}$ Amaney Jamal, "The Political Participation and Engagement of Muslim Americans: Mosque Involvement and Group Consciousness," American Politics Research 33, no. 4 (July 1, 2005): 521-44, https://doi.org/10.1177/1532673X04271385; Sukron Kamil and Zakiya Darojat, "Mosques and Muslim Social Integration: Study of External Integration of the Muslims," Insaniyat: Journal of Islam and Humanities 4, no. 1 (November 29, 2019): 37-48, https://doi.org/10.15408/insaniyat.v4i1.12119.

${ }^{11}$ Zain Ul Abideen and Farrukh Abbas, "Believers, Islamic Brotherhood and Mosque-Based Emotional and Informal Social Support System among Muslims in Pakistan,” Journal of Religion, Spirituality $\mathcal{E}$ Aging 33, no. 1 (January 2, 2021): 54-85, https://doi.org/10.1080/15528030.2020.1827480; Muhammad Imran Ibrahim, Mohd Nizam Sahad, and Suhaila Abdullah, "Pembangunan Remaja Masjid Masa Kini: Satu Tinjauan Di Masjid Daerah Kinta, Perak [Current Development of Mosque Youth: A Study at Daerah Kinta, Perak]," BITARA International Journal of Civilizational Studies and Human Sciences (e-ISSN: 2600-9080) 3, no. 3 (September 5, 2020): 168-83; Ummu Kultsum Nur Isnaini et al., "Revitalizing the Mosques Function as a Means of Forming Muslim Scholars and Students in Indonesia," Khalifa: Journal of Islamic Education 3, no. 2 (August 10, 2019): 142-53, https://doi.org/10.24036/kjie.v3i2.29; Faraaz Mahomed et al., "Establishing Good Practice for Human Rights-Based Approaches to Mental Health Care and Psychosocial Support in Kenya," Health and Human Rights Journal 22, no. 2 (October 19, 2020): 139-54; Yassar Mustafa et al., "The Role of Imams and Mosques in Health Promotion in Western Societies-a Systematic Review Protocol," Systematic Reviews 6, no. 1 (February 2, 2017): 25, https://doi.org/10.1186/s13643-016-0404-4; Ann W. Nguyen, "Mosque-Based Social 
It is worth noting that research has found a positive significant relationship between religious involvement and greater happiness, life satisfaction, morale, and other types of positive experiences. ${ }^{12}$ In this regard, many have reported that being in the mosques is not only spiritually rewarding but also socially satisfying. This promotes the well-being of the individuals, and in turn, their families, as well as the community. ${ }^{13}$ Research has also included the potential of religion being a vital part of combating issues that have existed and persisted through the pandemic such as health and well-being for all levels of society. ${ }^{14}$ In fact, this is a solution to help people who are psychologically affected by either the pandemic or the movement control order. Hence, with proper planning and full caution over the safety of the people against the virus, mosque activities should continue to take place for the benefit of the community.

The role of the mosque committee to ensure that the mosque can effectively and efficiently fulfill its own roles and responsibilities to serve the community is therefore crucial, even in places where there is a strong central agency (be in the state- or national-level) control such as Malaysia. Administrative incompetence will lead to erosion of trust from the public, making it difficult for mosques to

\footnotetext{
Support and Collective and Personal Self-Esteem Among Young Muslim American Adults,” Race and Social Problems 9, no. 2 (June 1, 2017): 95-101, https://doi.org/10.1007/s12552017-9196-y.

12 Jamal-e-Din MahdiNejad, Hamidreza Azemati, and Ali Sadeghi Habibabad, "Religion and Spirituality: Mental Health Arbitrage in the Body of Mosques Architecture," Journal of Religion and Health 59, no. 3 (June 1, 2020): 1635-51, https://doi.org/10.1007/s10943-019. 00949-w; Eleonora Papaleontiou - Louca, "Effects of Religion and Faith on Mental Health," New Ideas in Psychology 60 (January 1, 2021): 100833, https://doi.org/10.1016/j.newideapsych.2020.100833.

${ }^{13}$ Fagan, "Why Religion Matters Even More."

${ }^{14}$ Simon Dein, "Against the Stream: Religion and Mental Health - the Case for the Inclusion of Religion and Spirituality into Psychiatric Care," BJPsych Bulletin 42, no. 3 (June 2018): 127-29, https://doi.org/10.1192/bjb.2017.13; Simon Dein et al., "COVID-19, Mental Health and Religion: An Agenda for Future Research,” Mental Health, Religion $\mathcal{E}^{2}$ Culture 23, no. 1 (January 2, 2020): 1-9, https://doi.org/10.1080/13674676.2020.1768725.
} 
fulfill their role to provide viable and relevant programs, enabling mosques to become the "citadel" of knowledge they are supposed to be. ${ }^{15}$

Mosques are popular recipients of public funds. These funds are usually managed by the committee members, and in addition to covering the maintenance outlays, these funds may also be used to organize public courses, discourses, or other events. Hence, the need to ensure there is adequate internal control regarding the receipt and disbursement of these funds, and this is solely the purview of the mosque committee. ${ }^{16}$

In Malaysia, the appointment, and the terms of reference of the mosque committee members are regulated by the different states. Although they may vary slightly according to states, in general, all states have a provision in their religious state laws on the establishment of the mosque committee for each mosque in the state (e.g., Trengganu Administration of Islamic Religious Affairs (Administration of Mosques) Rules 1987.

This contrasts with the mosques in the United States where there is no one recognized governing body. However, even within this loose structure, in a study involving 331 mosques, $97 \%$ of the mosques have established an executive committee to investigate the operational matters of the mosques. ${ }^{17}$

In Indonesia, the structure of mosque management differs according to the type of mosque. A recent study to address the concerns that mosques may be the breeding ground of extremism

\footnotetext{
${ }^{15}$ Tajudeen Yusuf and Lukman AbdurRaheem, The Masjid (Mosque) Basics $\mathcal{E}$ Management, Second Edition (Dhaka, Bangladesh: District Global Concept, 2013).

${ }^{16}$ Maliah Sulaiman, "The Internal Control Procedures of Mosques in Malaysia," Revista Universo Contábil 3, no. 2 (2007): 101-15, https://doi.org/10.4270/ruc.20073.

${ }^{17}$ Ihsan A. Bagby, "Governance Issues in American Mosques: Exploring the Present and Making Recommendations for the Future," Journal of Islamic Faith and Practice 1, no. 1 (March 9, 2018): 40-54.
} 
highlighted the role that mosque committee plays in this aspect visa-vis their management of religious education programs. And this works both ways, these religious education programs may be a source of dissemination of the societal-building ethos. ${ }^{18}$ If the mosque's management is comprised of individuals who have a good and tolerant Indonesian mindset, then the program that emerges from the mosque will be of the same mindset as well. ${ }^{19}$

Yet, whatever the structure and the specific make-up of the community, and whether the mosque is in a Muslim-majority country like Malaysia and Indonesia or a Muslim-minority country like the United Kingdom or Germany, the central role of the mosque committee in ensuring that the mosque, in turn, can fulfill the objectives of its existence cannot be denied. As such, understanding how these committee members view their roles and conduct themselves is important to make any major initiative a success.

\section{METHODOLOGY}

This research adopts a qualitative research design to identify issues pertaining to the structure, and implementation of mosque education programs. The approach would enable the researchers to have unrestricted information which would lead to rich information about the existing condition of mosque education programs. For this study, the Focus Group Discussion (FGD) approach is used.

This study is a part of a larger study to understand the conduct, impact, and views on existing mosque education programs with

\footnotetext{
${ }^{18}$ Nining Islamiyah, Siti Siraj, and Ahmad Osman, "Internal Control Practices of Mosques in Java, Indonesia," Jurnal Akuntansi Dan Keuangan Indonesia 17, no. 1 (June 30, 2020): 84-101, https://doi.org/10.21002/jaki.2020.05; Rosita Tandos, Abd. Muid N, and Nasaruddin Umar, "Indonesian Mosques: Current Issues, Management, and Institutions in Indonesia and the United States," Journal of Islamic Studies and Culture 8, no. 2 (2020): 1-12, https://doi.org/10.15640/jisc.v8n2a1.

${ }^{19}$ Tandos, Muid N, and Umar, "Indonesian Mosques."
} 
various segments of the community, including the mosque committee. Several FGDs have been conducted to gather the views of mosque committee members about the religious classes conducted at their mosques. The FGDs were conducted face-to-face within a onemonth period. Depending on the size of the actual committee member of the mosque, the number of participants per FGD ranged from seven to eleven. As per the composition of the mosque committee, they were mostly all men with one and at most 2 women who headed the muslimat committee.

Representatives of committee members of mosques in Gombak have participated in the study. This study was conducted in Gombak, a Muslim-dominated district given its central location in Peninsular Malaysia. Given the size of the district, the study was able to capture views from the more urban areas and the suburban areas, as gazette by the State Religious Administrative Council.

The participants of the FGDs in this study comprised committee members of two urban area mosques and two suburban area mosques. The researchers, with the supporting document from the District Religious Department, contacted the management of the identified mosques informing the plan to conduct research on mosque education programs. Upon agreement of the management, a date to conduct the FGD was set with a request for the invitation to be extended to the entire committee. During the FGD, the committee members were briefed on the objective of the research, the research expected outcomes and the ways the FGD would be conducted. The FGD was facilitated by a facilitator, assisted by one rapporteur in each group. The FGD was conducted in the mosque itself, and for all four mosques, it was arranged to be done in the meeting room of the mosque.

Prior to conducting the FGD, the research team developed the major questions to be asked. This is to ensure that the necessary 
elements were covered, and the conduct of the FGD was relatively uniform across the different mosques while bearing in mind that the actual conduct would differ based on the responses of the participants. During the FGD itself, the moderator posted several questions to the groups to facilitate the discussion, probed with follow-up questions throughout the session. All the sessions were recorded and were later transcribed prior to the analysis.

\section{RESULT AND DISCUSSION}

The transcription from the FGD was then subjected to a content analysis according to the pre-identified themes based on the objectives of the study.

The findings of the study are presented in several pre-identified themes, namely the education activities, the resource person, the program participants, the education content, the teaching and learning approaches, the expected outcomes, and impact, plus other aspects that came up during the FGD that did not fall into any of the said themes.

\section{The Mosque Education Activities}

The mosques in this study were active in conducting educational programs at their respective places, in that there was almost always one program each day. The following table shows an example of the programs that have been conducted at one of the mosques and how frequent they were conducted:

Table 1. Mosque Programs

\begin{tabular}{|l|l|}
\hline Maghrib Lecture & $\begin{array}{l}\text { Conducted daily except on Thursday, as } \\
\text { it is reserved for Yasin Recitation }\end{array}$ \\
\hline Fajr Lecture & $\begin{array}{l}\text { Conducted every Saturday, Sunday, and } \\
\text { public holidays }\end{array}$ \\
\hline
\end{tabular}


Shukran Abdul Rahman dkk.

\begin{tabular}{|l|l|}
\hline Dhuha Lecture & Conducted four times per week, \\
\hline Asr Lecture & Conducted four times per week \\
\hline Special Lecture & Conducted monthly, by invited speakers \\
\hline Forum & Conducted once in every three months \\
\hline Jumaat Lecture & Conducted before Jumu'ah time \\
\hline $\begin{array}{l}\text { Special } \\
\text { programs }\end{array}$ & $\begin{array}{l}\text { Janazah Management Program, Umrah } \\
\text { and Hajj Courses, etc. }\end{array}$ \\
\hline
\end{tabular}

The type of activities and frequency of conduct was similar across all the mosques, with variations in the specific days or actual frequency of the conduct. This is a piece of important information as the knowledge of the frequency of activities at the mosques may serve as a guide for module developers to develop the curriculum. More importantly, it also indicated that the mosque committee were very keen to organize religious education classes for the masses.

\section{The Resource Person}

The interviewees highlighted the issue with the resource people whom the mosque needed to identify in conducting the educational activities at the mosque. This, as stated by the interviewees, should be someone who was to be selected properly based on their ability to conduct the programs appropriately, attract the audience and deliver effective teaching.

It was found that there was somehow a lacuna of suitable teachers/speakers to teach young children, especially the boys. According to the interview participants, there have been cases when teachers were appointed based on convenience, in that anybody could be appointed to teach without checking their suitability. They 
have also mentioned that the existing programs at the mosques were to be conducted by Ustaz and Ustazah who have received permission from the State Religious Department who all subscribe to the Ahlus sunnah wal jamaah school of ethics, fiqh, and creed. At times, notable influencers among experts, scholars, and celebrities were also invited as they would attract huge crowd participation.

Hence, as much as the mosque committee attempted to adhere to the requirements of the State Religious Department, there were occasions when they had to make do with who was available. More significantly though, a permit to teach in mosques given by the State Religious Department was only an assurance of the speaker's acceptable manhaj, not of the speaker's ability to deliver the content effectively.

\section{The Program Participants}

Interviewees were also asked about the volume of participants in these education programs. According to them, the number of participants depended on the type of classes which would generally vary from time to time. Interviewees said that the post-Maghrib lecture would be attended by about 25 to 100 participants while an Arabic class held during the day would be attended by 5 participants only. A Premier talk or Ceramah Perdana on the other hand would be attended by a huge crowd, as per the goal of the program.

The target groups for the programs organized at the mosque varied, which may also include young children. Given the average number of individuals who attended the five daily congregational prayers was 100, this would be a considerable number of potential audiences to the programs connected to the prayer times. It was also found that community members prefer musolla nearer their houses to the mosque to perform their congregational prayers or religious 
classes, hence the small number of people going to the mosque itself relative to the number of Muslims in the community.

This meant that each mosque may draw more crowds if it was geographically convenient for the surrounding residents, hence should be regarded as key to the proposed curriculum. Additionally, the nature of the program influences the volume of participants, indicative of the need for curriculum developers to pay attention to the type of module or activities to ensure the curriculum is effectively delivered to a bigger number of people in society.

\section{The Education Content}

The content of the religious class was also asked in the interview. The FGD participants were informed that the actual content was determined by the appointed teachers instead of the mosque committee. A nazir once informed the committee of one of the mosques in this study that priorities were to be given to textbased classes (Kitab-based which refers to classical text or contemporary texts) in the mosque he managed. Moreover, the subject matter was usually one which was more easily understood by the masses as opposed to a heavy subject matter such as philosophy.

It was found that the content of these classes was heavily monitored by the State Religious Department, and the mosque committee was entrusted to ensure compliance with the allowed content. This would need to be given due attention in developing a mosque religious education curriculum. Whether this would continue to be a viable approach for a mosque in the 21st century remained to be seen.

\section{The Teaching and Learning Approaches}

The issue of the pedagogical approach of these classes was also discussed in the FGD. The participants indicated that a class should 
completely cover the chosen text (kitab) so as to bring about benefits to participants in their daily life. A series of classes may then take a long time (i.e., years) to completely cover the chosen text when the class was held once a week. In some cases, once the text was covered it was repeated anew.

According to the FGD participants, there was no education programs that were conducted via the daurah approach. Daurah refers to an intensive text-based class in which the content is structured by the teacher. The monitoring of the conduct of the classes by the mosque committee was more focused on the content instead of the pedagogical approach and hence, there was not much information to be gathered.

\section{The Expected Outcomes}

The significance and importance of mosque education programs were also laid out by the FGD participants. Firstly, to enhance the right understanding of Islam among Muslims, which was important to guide them to function in family and society. Misleading information to the public especially about society may lead them to the wrong path from what has been taught in the Quran and the Sunnah. Next was to educate moral conduct and nurture good behaviors among adolescents. This signified the need to prepare the next generation of Muslims and non-Muslims on good morals and behavior that point towards a society laden with Sejahtera values. 
Table 2. Significance/Importance of Mosque Education Programs

1. To enhance the right understanding of Islam among Muslims, important for them to guide them to function in family and society

2. To educate moral conducts and nurture good behaviors among adolescents

3. To obtain blessings and mercy from Allah onto the locality in general. A committee member said 'Mengundang rahmat Allah SWT kepada seluruh anak kariah'

4. To reduce the divide or animosity among members in the society

5. To address social issues and collectively provide solutions to the issues.

The FGD participants felt that the significance of the programs was to obtain blessings and mercy from Allah onto the locality in general. A committee member said 'Mengundang rahmat Allah SWT kepada seluruh anak kariah", which means inviting the blessing of Allah SWT towards all the members of the society. This is also what was taught to Muslims in the Islamic teaching which coincides with the point of fardhu kifayah which supports the society not exclusively to Muslims but the society as a whole. ${ }^{20}$ Another significance is to reduce the divide or animosity among members of society. This was also an important takeaway to note from the discussions with the FGD participants. As the Quranic and prophetic teachings talk about being merciful to all people, the issue of friction and division in the society of all backgrounds may also be put in focus within this curriculum.

\footnotetext{
${ }^{20}$ Barni and Mahdany, "Al Ghazāli's Thoughts on Islamic Education Curriculum."
} 
Lastly was to address social issues and collectively provide solutions to the issues. This was certainly a point that was well taken from the discussion with the FGD participants. This idea must be pushed to be materialized to the best possible effect so that all levels and backgrounds of society can benefit from the intended curriculum.

\section{The Impact}

There was no evaluation on the effectiveness of the religious classes or satisfaction of the participants on the education programs being conducted at the mosques. The non-existence of an evaluation system may have been the cause for the difficulties to find a proper teacher and maintain a good level of quality teaching for the classgoers. Hence, this meant that there was no avenue for a systematic continual quality improvement to be implemented about these programs, which is a concern given the potential impact of these programs.

\section{Other Issues and Challenges in Mosque Education Programs}

Other issues and challenges in mosque education programs were also procured during the FGD: attitudes of participants towards religious class, participation, quality of the class, and teachers' competencies.

Table 3. Issues and challenges in Mosque Education Programs

1. Negative Attitudes of participants towards religious class

2. Little response from the society to attend the programs

3. The focus is on the frequency rather than the quality of class 
Shukran Abdul Rahman dkk.

4. Lack of suitable teachers/speakers to teach young male children

On attitudes of participants towards religious classes, the FGD participants said that many mosque-goers did not give serious attention to the religious classes conducted in the mosques. In other words, they took the classes for granted that many did not remember the content being taught by the speakers or teachers. This may be due to a lack of interest or even a lack of incentives for them to be interested in the class discussion, to begin with. It may be born out of the lack of awareness from the public of the importance or the beauty of Islam that was delivered through its teachings via various fields of knowledge within Islamic teaching.

On participation of the mosque-goers, it was found that despite the availability of many mosque education programs, there has been little response from the surrounding community to attend the programs. A committee member said "masjid aktif mengadakan kuliah namun tiada sambutan dari masyarakat" or that the mosque frequently organized religious classes but there was little participation from the community. Developers of the module must get to the bottom of this as to why the society did not feel engaged with the organizers in their many events. It may be down to various reasons; unattractive programs, programs that do not meet the needs of the people, the way these programs were delivered, or more.

On the quality of the classes, interviewees said that many mosques gave priority to making sure that there were religious classes being regularly conducted instead of on ensuring the selection of suitable teachers. The lack of attention to the person delivering the contents of the classes has perhaps paved the way to the lack of quality of the classes. Moreover, interview participants have also been informed that there has been a lack of improvement on the level of class quality, most of the content being repeated due 
to the change of teachers appointed by the mosque. This points to the low control of quality from the class organizers in exchange for the need to constantly have class every other day. This may have caused mosque-goers to be less interested in repetitive content that does not add to their existing knowledge. Moreover, this may cause an issue in the teacher-student relationship. As more teachers were replaced, mosque-goers may have to adapt to more teachers over time. This overtime may make them feel less connected and attached to the people of the mosque because teachers will be replaced anyway. This may also present the new incoming teachers with an obstacle to connecting with the students, which then impedes the quality of the class however able the teachers are.

\section{Suggested Approaches to be Taken by Mosques in Promoting Religious Education Programs}

Below are the suggested approaches for the mosques in promoting religious education programs. The approaches are thematised into the following themes:

Table 4. Suggested Approaches

\begin{tabular}{|c|c|}
\hline & SUGGESTIONS \\
\hline $\begin{array}{l}\text { Mosque } \\
\text { Management }\end{array}$ & $\begin{array}{l}\text { a. Mosque Management to emulate mosque } \\
\text { management in other countries with effective } \\
\text { education programs (e.g. Singapore) } \\
\text { b. The existing coverage of content in Text-based } \\
\text { Class should continue for they are important } \\
\text { to re-educate people including those who } \\
\text { recently participate in the religious class } \\
\text { programs. } \\
\text { c. Loud speaker should be allowed in order to } \\
\text { allow people to follow talk/lecturers from the } \\
\text { mosques without having to enter mosques, }\end{array}$ \\
\hline
\end{tabular}


Shukran Abdul Rahman dkk.

\begin{tabular}{|l|l|}
\hline $\mid$ & especially among women. \\
\hline $\begin{array}{l}\text { Content of } \\
\text { classes }\end{array}$ & $\begin{array}{l}\text { a. } \\
\text { In-depth study classes on a series of selected } \\
\text { text, from lower to advanced level, must be } \\
\text { have been spending longer time in the } \\
\text { program } \\
\text { b. } \begin{array}{l}\text { Class on a specific topic should be organized } \\
\text { periodically } \\
\text { c. }\end{array} \\
\text { Arabic class should be organized if there is } \\
\text { request for it }\end{array}$ \\
\hline
\end{tabular}




\begin{tabular}{|l|l|}
\hline & $\begin{array}{l}\text { a. } \begin{array}{l}\text { Participants should be invited to join the class } \\
\text { by using gentle and appropriate approaches }\end{array} \\
\text { b. } \begin{array}{l}\text { Participants and mosques are dealt with in } \\
\text { polite ways, avoiding approaches that would } \\
\text { make them shun away from the mosque. }\end{array} \\
\text { Engagement } \\
\text { with various } \\
\text { cypes of }\end{array} \quad \begin{array}{l}\text { Mosque committee members should adopt } \\
\text { and allow leisure manner while in the } \\
\text { mosque, instead of applying unnecessary } \\
\text { strict rules for mosque-goers. The latter might } \\
\text { make people feel unwelcome to the mosques }\end{array}$ \\
d. $\begin{array}{l}\text { Mosques should be open to the surrounding } \\
\text { community. Mosques should set 'WhatsApp } \\
\text { Group (WAG)', managed by Mosque } \\
\text { Committee in order to manage, promote and } \\
\text { coordinate religious classes in the mosque } \\
\text { eecognize the participation of community } \\
\text { members by giving them certificates of } \\
\text { attendance or achievement for their } \\
\text { involvement in class activities. }\end{array}$ \\
\hline
\end{tabular}




\begin{tabular}{|c|c|}
\hline $\begin{array}{l}\text { Resource } \\
\text { People }\end{array}$ & $\begin{array}{l}\text { a. Resources for volunteers should be made } \\
\text { available so that they can provide educational } \\
\text { programs, other than religious classes, to the } \\
\text { community. Volunteers may be engaged from } \\
\text { higher education institutions or any relevant } \\
\text { agencies. } \\
\text { b. Speakers among young people are to be } \\
\text { included as resource people/teachers, } \\
\text { enabling them to acquire experience of } \\
\text { teaching in mosques } \\
\text { c. Set salient specifications of speakers in the } \\
\text { criteria of selection for teachers, namely } \\
\text { i. skills to attract the audience, new } \\
\text { participants. } \\
\text { ii. abilities to conduct classes in a less } \\
\text { formal manner, to accommodate } \\
\text { audiences with diverse } \\
\text { backgrounds. } \\
\text { iii. ability to provide experiential } \\
\text { learning or daurah type of approach }\end{array}$ \\
\hline $\begin{array}{l}\text { Diversify } \\
\text { Mosque } \\
\text { Activities }\end{array}$ & $\begin{array}{l}\text { a. Free food or food-bank programs. } \\
\text { b. Community development programs for } \\
\text { children, youth, and women } \\
\text { c. Counseling services to the community }\end{array}$ \\
\hline
\end{tabular}

The first suggestion is on the management of the mosque. It is encouraged that the mosque management emulate mosque 
management in Singapore who have seen success in engaging the society in their area. Their approach revolves around open and strategic management to a point where social and religious harmony is possible. Still, considering the comparison that exists between Malaysia and Singapore in terms of their demographic, political, and historical background, there are indeed many positives that can be drawn from the module that the Singaporeans have been using so successfully thus far.

The second suggestion is on the content of classes. A committee should be established to ensure that the quality of the classes continues to improve. In-depth study classes on a series of selected texts, from lower to advanced levels, must be conducted to accommodate participants who have been spending longer time in the program. This is to also establish a sense of accomplishment to long-time mosque-goers who have been following the classes for a long time. This is also to encourage new mosque-goers, or anyone interested to learn the knowledge to complete the series as they are not too long that it bores them, and it comes in levels. Hence, classes on specific topics should be organized periodically and Arabic classes which were found to attract the least participants should be organized upon request. The existing coverage of content in textbased classes should continue for they are important to re-educate people including those who recently participate in the religious class programs. Loudspeakers should be allowed to allow people to follow talk/lecturers from the mosques without having to enter mosques, especially among women.

The third suggestion is engagement with various types of community. This approach to diversify the engagement between the community is to attract new participants to the class by using gentle and appropriate approaches. Moreover, this approach will instill an idea to the mosque management to deal with participants and 
mosques in polite ways, avoiding approaches that would make them shun away from the mosque. Mosque committee members should adopt and allow leisure manner while in the mosque, instead of applying unnecessary strict rules for mosque-goers. The latter might make people feel unwelcome to the mosques. Furthermore, mosques should be open to the surrounding community. This would allow a sense of openness and welcome to anyone surrounding the mosque. Mosques should also set WhatsApp group, managed by Mosque Committee to manage, promote and coordinate religious classes in the mosque. This is to ensure that there is coordination in any event organized by the mosque and that it allows a medium for the mosque to share news relevant to the community. Then is to recognize the participation of community members by giving them the certificate of attendance or achievement for their involvement in class activities.

The fourth suggestion is on the resource people. To avail resources for volunteers to provide educational programs, other than religious classes, to the community. Volunteers may be engaged from higher education institutions or any relevant agencies. This not only benefits the mosque but also the volunteers from varsities as they may consider these programs as part of their experience through flagship programs or corporate social responsibility events. Next is to appoint speakers among young people, enabling them to acquire experience of teaching in mosques. This will also present the mosque as an entity that welcomes young people to share their talents and lead society in some capacity. This not only engages the mosque management with the youth, but it also ensures that the management will continue to be sustainable for years to come as more youth will come into responsibility for the mosque in their area. To do so, a certain specification of speakers in events as well as teachers must be included in the criteria of selection. Among the 
specifications are: skills to attract the audience that includes new participants, abilities to conduct classes in a less formal manner to accommodate audiences with diverse backgrounds and ability to provide experiential learning or daurah type of approach.

The last suggestion is on diversifying the mosque activities. Mosques should hold charity events for their locals in the form of donations, Ramadhan feast, or even free food or food-bank programs. In addition, the mosque should open its doors to the locals to hold various events that are not just religious classes within the mosque compound or vicinity such as health and exercise programs, public speaking and debate competitions, or even formal lectures such as lectures for Aids awareness by the Health Ministry or awareness on crimes by the Malaysian Royal Police. Mosques could organize monthly invitations for the society to beautify the mosque in gotong-royong. They should invite all levels of society including the ladies and the children to do activities at the mosques, not just the males which were always the usual. This could be incorporated in Islamic mural competitions at a section of the mosque, gardening competitions, or even an installation of a playground for the children.

The main idea of the last suggestion is to ensure that the mosque is always connected with the people around the mosque and does not always or only focus on things that may disconnect them from the people such as very long classes etc. This is so that everyone feels connected to the mosque and that the mosque is somewhere they could go to spend time. Charity events could also benefit people who are non-Muslims who live in the area. The challenge of this suggestion may come from the question of financial, as to how the mosque will be able to finance certain events such as competitions or feasts. This may also become an opportunity for the mosque to get to know and engage with key people in their society better. This allows 
for more opportunities to cooperate with people who might have the necessary resources be it network or connections, materials, or even money. This will further strengthen the bond of the mosque and the people not only through fun and beneficial programs designed specifically for the people but also through strong relationships and a sense of trust between the mosque and the community.

\section{CONCLUSION}

The findings of the study reinforced the initial concerns that as much as the mosque committee understood their roles in providing religious education programs for the public, many of them were more particular on the regulation and compliance to the authorities than the quality and the impact of the programs.

The FGDs also allowed the researchers to appreciate the commitment these committee members had. They were volunteers who were un-paid and did not expect to be paid, as they held fulltime jobs elsewhere. That they were able to maintain the level of activities these mosques were offering to the public was a significant detail to be taken note of. Many of these committee members were working professionals or were retirees who held management jobs before their retirement. It would be good if they were to systematically apply some of the quality assurance principles of their regular jobs to the religious education classes too.

Although the study was done within one district in Malaysia, the suggestions listed above may be applicable to mosques globally, as the functions of the mosques across the world should be in the spirit of the mosques during the times of the Prophet and the earlier periods of Islam. Mosques should continue to be the knowledge centers, or the "citadel of learning," in the pursuit of rahmatan lil 'alamin. To this point, the mosque committee should be constantly reflecting on their own roles and the potential good they may affect 
in carrying out their duties, hence why studies like this should continue to be done around the world. Understanding the views of the mosque committee members will enable a better perspective in developing any initiative from an external party (be it the government), as the implementors of these initiatives will be these committee members. Instead of treading on each other's feet, engagement and collaboration should be the way to go to ensure that mosques become centers of excellence.

\section{Funding}

This research is supported by International Islamic University Malaysia under IIUM Flagship Research Initiative Grant Scheme and Mosque Development Division, Selangor Islamic Religious Department (Jabatan Agama Islam Selangor - JAIS) with title: A New Standard for Mosque Curriculum in Gombak

\section{REFERENCES}

Abideen, Zain Ul, and Farrukh Abbas. "Believers, Islamic Brotherhood and Mosque-Based Emotional and Informal Social Support System among Muslims in Pakistan." Journal of Religion, Spirituality \& Aging 33, no. 1 (January 2, 2021): 54-85. https:// doi.org/10.1080/15528030.2020.1827480.

Alfaraidy, Maryam, and Raffaello Furlan. "Sense of Community in Al-Wakrah City: Strategies for the Development of Sustainable Communities in Qatar." Saudi Journal of Engineering and Technology 2, no. 11 (2017): 390-402. https://doi.org/10.21276/sjeat.2017.2.11.1.

Al-Krenawi, Alean. "The Role of the Mosque and Its Relevance to Social Work." International Social Work 59, no. 3 (May 1, 2016): 359-67. https:/ / doi.org/10.1177/0020872815626997. 
Ata, Abe W. "Perception of Muslims and Islam in Australian Schools: A National Survey." In Religion and Social Problems, edited by Titus Hjelm, 1st Edition. London, UK: Routledge, 2010.

Bagby, Ihsan A. "Governance Issues in American Mosques: Exploring the Present and Making Recommendations for the Future." Journal of Islamic Faith and Practice 1, no. 1 (March 9, 2018): 40-54.

Barni, Mahyuddin, and Diny Mahdany. “Al Ghazāli's Thoughts on Islamic Education Curriculum." Dinamika Ilmu: Jurnal Pendidikan, December 31, 2017, 251-60. https://doi.org/10.21093/di.v17i2.921.

Dein, Simon. "Against the Stream: Religion and Mental Health - the Case for the Inclusion of Religion and Spirituality into Psychiatric Care." BJPsych Bulletin 42, no. 3 (June 2018): 12729. https://doi.org/10.1192/bjb.2017.13.

Dein, Simon, Kate Loewenthal, Christopher Alan Lewis, and Kenneth I. Pargament. "COVID-19, Mental Health and Religion: An Agenda for Future Research." Mental Health, Religion $\mathcal{E}$ Culture 23, no. 1 (January 2, 2020): 1-9. https:/ / doi.org/10.1080/13674676.2020.1768725.

Dewiyanti, Dhini, and Hanson E. Kusuma. "Spaces for Muslims Spiritual Meanings." Procedia - Social and Behavioral Sciences, AcE-Bs 2012 Bangkok, Sukosol Hotel, Bangkok, Thailand, 1618 July, 2012, 50 (January 1, 2012): 969-78. https:// doi.org/10.1016/j.sbspro.2012.08.098.

El-Menouar, Yasemin, and Melanie Becker. "Islam and Integration in German Media Discourse." In Religion and Social Problems, edited by Titus Hjelm, 1st Edition. London, UK: Routledge, 2010.

Fagan, Patrick. "Why Religion Matters Even More: The Impact of Religious Practice on Social Stability." Backgrounder. Washington, DC: The Heritage Foundation, December 18, 2006. https://www.heritage.org/civil-society/report/why- 
religion-matters-even-more-the-impact-religious-practicesocial-stability.

Harbi Hayette. "The Role of the Mosques in Promoting Cohesion in the American Community." Revue Académique Des Études Humaines et Sociales 19 (2018): 75-80.

Ibrahim, Muhammad Imran, Mohd Nizam Sahad, and Suhaila Abdullah. "Pembangunan Remaja Masjid Masa Kini: Satu Tinjauan Di Masjid Daerah Kinta, Perak [Current Development of Mosque Youth: A Study at Daerah Kinta, Perak]." BITARA International Journal of Civilizational Studies and Human Sciences (e-ISSN: 2600-9080) 3, no. 3 (September 5, 2020): 168-83.

Islamiyah, Nining, Siti Siraj, and Ahmad Osman. "Internal Control Practices of Mosques in Java, Indonesia." Jurnal Akuntansi Dan Keuangan Indonesia 17, no. 1 (June 30, 2020): 84-101. https:// doi.org/10.21002/jaki.2020.05.

Isnaini, Ummu Kultsum Nur, Billa Ratuwibawa Nyimasmukti, Yunus Rahawarin, and Asrida Asrida. "Revitalizing the Mosques Function as a Means of Forming Muslim Scholars and Students in Indonesia." Khalifa: Journal of Islamic Education 3, no. 2 (August 10, 2019): 142-53. https:// doi.org/10.24036/kjie.v3i2.29.

Jamal, Amaney. "The Political Participation and Engagement of Muslim Americans: Mosque Involvement and Group Consciousness." American Politics Research 33, no. 4 (July 1, 2005): 521-44. https://doi.org/10.1177/1532673X04271385.

Johnson, Byron R., Ralph Brett Tompkins, and Derek Webb. "Objective Hope: Assessing the Effectiveness of Faith-Based Organizations: A Review of the Literature." New York, NY: Center for Research on Religion and Urban Civil Society, Manhattan Institute, January 2, 2002. https:/ / media4.manhattaninstitute.org/pdf/crrucs_objective_hope.pdf. 
Shukran Abdul Rahman dkk.

Kamil, Sukron, and Zakiya Darojat. "Mosques and Muslim Social Integration: Study of External Integration of the Muslims." Insaniyat: Journal of Islam and Humanities 4, no. 1 (November 29, 2019):

$37-48$.

https:// doi.org/10.15408/insaniyat.v4i1.12119.

MahdiNejad, Jamal-e-Din, Hamidreza Azemati, and Ali Sadeghi Habibabad. "Religion and Spirituality: Mental Health Arbitrage in the Body of Mosques Architecture." Journal of Religion and Health 59, no. 3 (June 1, 2020): 1635-51. https:// doi.org/10.1007/s10943-019-00949-w.

Mahfud, Choirul. "Chinese Muslim Community Development in Contemporary Indonesia: Experiences of PITI in East Java." Studia Islamika 25, no. 3 (December 4, 2018): 471-502. https:// doi.org/10.15408/sdi.v25i3.6755.

Mahomed, Faraaz, Jacqueline Bhabha, Michael Ashley Stein, and Dainius Pūras. "Establishing Good Practice for Human Rights-Based Approaches to Mental Health Care and Psychosocial Support in Kenya." Health and Human Rights Journal 22, no. 2 (October 19, 2020): 139-54.

Maliah Sulaiman. "The Internal Control Procedures of Mosques in Malaysia." Revista Universo Contábil 3, no. 2 (2007): 101-15. https://doi.org/10.4270/ruc.20073.

Md. Noon, Hazizan, Mohamed Aslam Mohamed Haneef, Selamah Abdullah Yusof, and Ruzita Mohd. Amin. "Religiosity and Social Problems in Malaysia." Intellectual Discourse 11, no. 1 (June 30, 2003): 77-87.

Mohamed, Intan Salwani, Noor Hidayah Ab Aziz, Mohamad Noorman Masrek, and Norzaidi Mohd Daud. "Mosque Fund Management: Issues on Accountability and Internal Controls." Procedia - Social and Behavioral Sciences 145 (August 25, 2014): 189-94. https://doi.org/10.1016/j.sbspro.2014.06.026.

Mustafa, Yassar, Diya Baker, Preeti Puligari, Teresa Melody, Joyce Yeung, and Fang Gao-Smith. "The Role of Imams and 
Mosques in Health Promotion in Western Societies-a Systematic Review Protocol." Systematic Reviews 6, no. 1 (February 2, 2017): 25. https://doi.org/10.1186/s13643-0160404-4.

Nguyen, Ann W. “Mosque-Based Social Support and Collective and Personal Self-Esteem Among Young Muslim American Adults." Race and Social Problems 9, no. 2 (June 1, 2017): 95-101. https:/ / doi.org/10.1007/s12552-017-9196-y.

Omar, Nizaita, Zulkifly Muda, Razi Yaakob, and Kasyfullah Abdul Kadir. "Framework of Empowering Mosque Institution in Malaysia." International Journal of Academic Research in Business and Social Sciences 9, no. 9 (September 25, 2019): 753-62.

Omer, Spahic. "Some Lessons from Prophet Muhammad (SAW) in Architecture: The Prophet's Mosque in Madinah." Intellectual Discourse 18, no. 1 (June 29, 2010): 115-40.

- - - "The Form and Function of the Prophet's Mosque during the Time of the Prophet." Muslim Heritage (blog), August 4, 2020. https:// muslimheritage.com/function-of-the-prophetmosque/.

Oruç, Cemil. "The Impacts of Religious Education on Individual and Social Life." Dinbilimleri Akademik Araştırma Dergisi 10, no. 3 (June 1, 2010): 195-211.

Papaleontiou - Louca, Eleonora. "Effects of Religion and Faith on Mental Health." New Ideas in Psychology 60 (January 1, 2021): 100833. https://doi.org/10.1016/j.newideapsych.2020.100833.

Tandos, Rosita, Abd. Muid N, and Nasaruddin Umar. "Indonesian Mosques: Current Issues, Management, and Institutions in Indonesia and the United States." Journal of Islamic Studies and $\begin{array}{lllll}\text { Culture } & 8, & \text { no. } & 2 & \text { (2020): } \\ 1-12 .\end{array}$ https:// doi.org/10.15640/jisc.v8n2a1.

The Pew Research Center. "Worldwide, Many See Belief in God as Essential to Morality." Washington, DC: The Pew Research 
Shukran Abdul Rahman dkk.

Center,

March

13 ,

2014.

https://www.pewresearch.org/global/2014/03/13/worldwi de-many-see-belief-in-god-as-essential-to-morality $/$.

Waugh, Earle H. Al Rashid Mosque: Building Canadian Muslim Communities. Edmonton, Alberta, Canada: University of Alberta Press, 2018.

Yïğitoğlu, Mustafa, and Mustafa Göregen. "Economic and Commercial Relations of the Prophet Muhammad with the Jews." Afro Eurasian Studies 7, no. 2 (December 31, 2018): 23653. https://doi.org/10.33722/afes.475785.

Yusuf, Tajudeen, and Lukman AbdurRaheem. The Masjid (Mosque) Basics \& Management. Second Edition. Dhaka, Bangladesh: District Global Concept, 2013. 